\title{
Managing Floodplain Forests for Bird Diversity
}

\section{Floodplain Succession}

With their complex and dynamic interactions of plants, animals, bacteria, fungi, and insects, forest ecosystems are constantly changing. Succession, a natural and predictable process of regrowth and change, occurs in an ecosystem over time. In floodplains of the Upper Mississippi River, the successional sequence of trees is a pioneering or young cottonwood-willow community (Populus deltoides, Salix spp.), a transitional cottonwood-silver maple (Populus deltoides, Acer saccharinum) community, and a mature community of silver maple, elm (Ulmus spp.), and ash (Fraxinus $s p p$.). Once a floodplain forest reaches maturity, age, disease or other disturbance causes the successional sequence to begin again with a young forest.

Along the Mississippi River north of its confluence with the Ohio River, most floodplain forests are dominated by aging silver maples, established shortly after the locks and dams were built in the 1930s. Forest managers predict widespread replacement of these aging forests by earlier stages of succession, including young cottonwood and willow, over the next decades. In the wettest locations, managers worry that forests may be replaced by grasslands dominated by invasive species such as reed canary grass (Phalaris). Currently, young floodplain forests dominated by cottonwood and willow are uncommon along the Mississippi River.

\section{Forests for Nesting Birds}

Previous research by USGS in the Upper Mississippi River and Lower Mississippi Alluvial Valley demonstrated that mature floodplain forests provide important breeding habitat for a large group of birds, many of which are of concern to the U.S. Fish and Wildlife Service (FWS), the Federal agency with management responsibility for migratory birds in the U.S. Bald eagles (Haliaeetus leucocephalus), red-shouldered hawks (Buteo lineatus), and cerulean warblers (Dendroica cerulea), all bird species of management concern, favor mature forests for nesting.

\begin{abstract}
The USGS Upper Midwest Environmental Sciences Center recently completed a study that will help state and Federal agencies such as FWS make decisions about bird conservation and management of large river floodplains. Because little is known about which bird species nest in young floodplain forests, we studied birds of young cottonwood and willow forests at two sites and compared them with adjacent shrub habitats and mature silver maple forests. During the summer of 2001 we studied Harlow and Wilkinson Islands, sites owned by the FWS that have large (100-250 ha) stands of young floodplain forests.
\end{abstract}

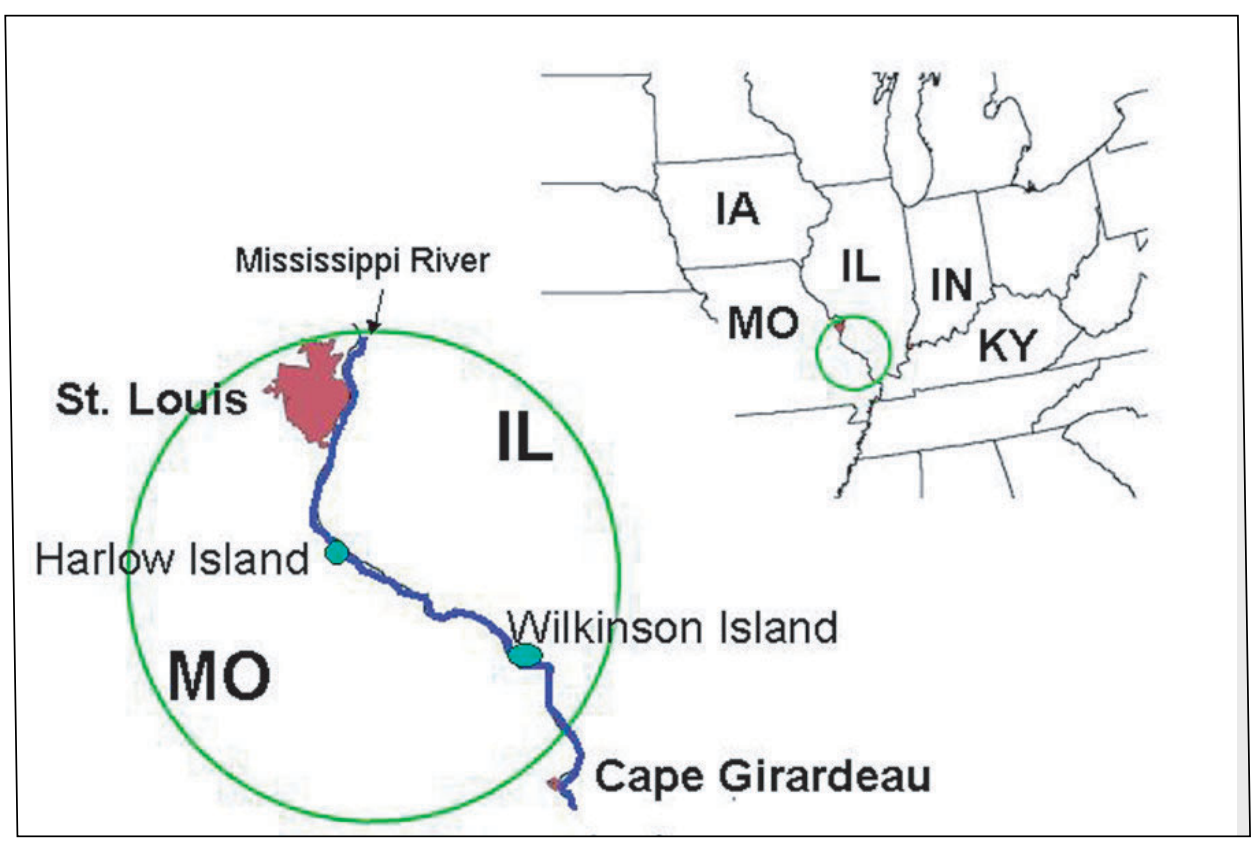

The study area was located south of St. Louis, Missouri. Both sites were located in the floodplain of the Middle Mississippi River. 


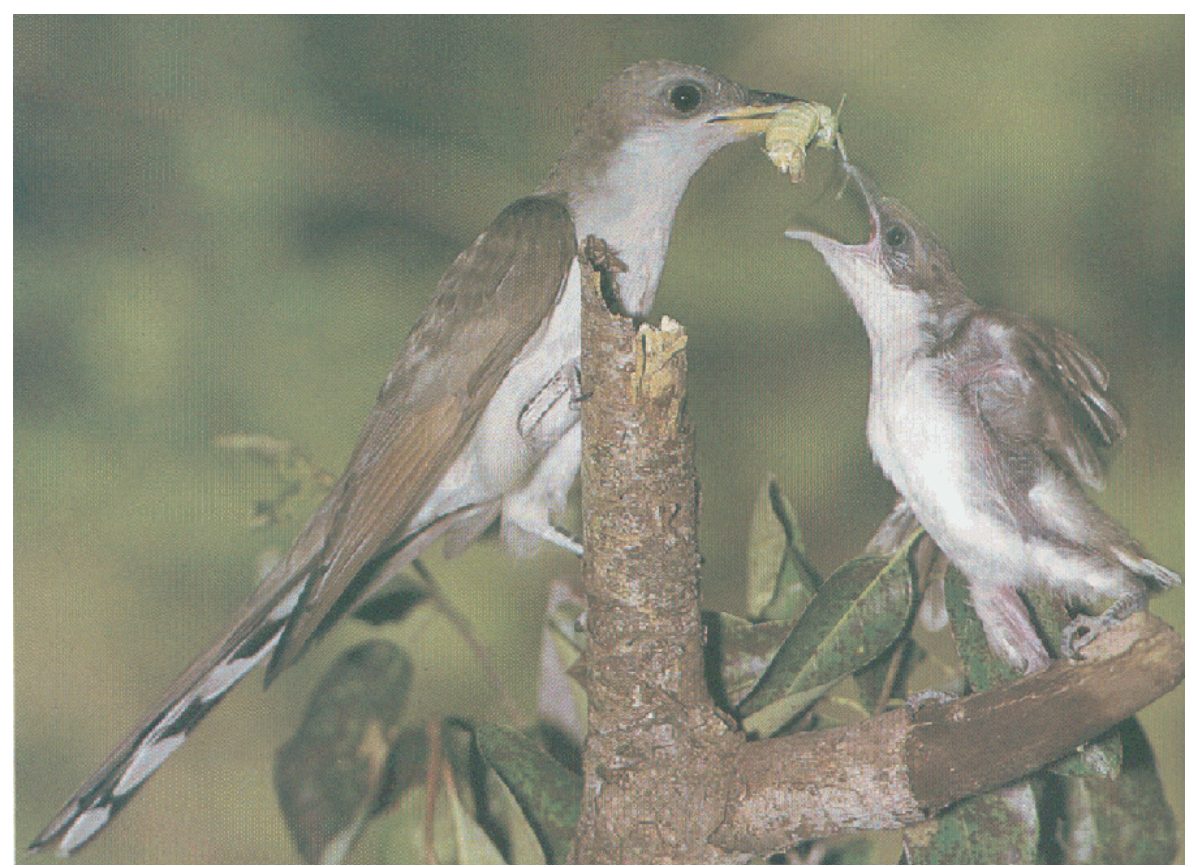

The yellow-billed cuckoo was one of the most common species in our study area.

Our study showed that the three habitat types (young forests, open shrub habitats, and mature forests) together supported a diversity of bird species (69 species). The species we most frequently observed were the indigo bunting (Passerina cyanea), red-winged blackbird (Agelaius phoeniceus), and yellow-billed cuckoo (Coccyzus americanus). Mature silver maple-dominated forests supported the largest number of bird species (46) compared with the young forests and shrub habitats, which hosted 34 and 38 species, respectively. The open habitat and mature forest each had distinct bird communities not shared with the other habitats, but the young forests shared a number of species with the other two habitat types. No species emerged as an indicator of young cottonwood-willow forests, but the shrub/scrub and mature forest habitats were each associated with a set of indicator bird species. We detected several bird species of management concern, including the orchard oriole (Icterus spurious) and the field sparrow (Spizella pusilla) in the young forests; the dickcissel (Spiza americana) in the open habitat; and the red-headed woodpecker (Melanerpes erythrocephalus), northern flicker (Colaptes auratus), Kentucky warbler (Oporornis formosus), Acadian flycatcher
For more information on large floodplain forests, see the following publication: Urich, R., G. Swenson, and E. Nelson, editors. 2002. Upper Mississippi River and Illinois River floodplain forests. Upper Mississippi River Conservation Committee, Rock Island, Illinois, USA: http://www.mississippi-river.com/ umrec/.

\section{For more information, contact}

\author{
Melinda Knutson \\ USGS Upper Midwest Environmental \\ Sciences Center \\ 2630 Fanta Reed Road \\ La Crosse, WI 54603 \\ Phone: 608.781 .6339 \\ Fax: 608.783.6066 \\ mknutson@usgs.gov
}

\section{http://www.umesc.usgs.gov/}

(Empidonax virescens), and wood thrush (Hylocichla mustelina) in mature floodplain forests. The bird assemblage we observed in young forests may become more prevalent as many aging floodplain forests are replaced with younger stages of forest succession. Under this scenario, we would predict a temporary local decrease in bird species richness and habitat for species of management concern along the Mississippi River. Over time, however, these young forests will mature into forests rich in bird species. Management should focus on restoring mature forests with a diversity of tree species. Long-term management should also strive to diversify forest age structure across the region, creating a shifting mosaic of floodplain forests of different ages and tree species. These actions will best restore and sustain forest habitats needed by many bird species, including those most in need of management.

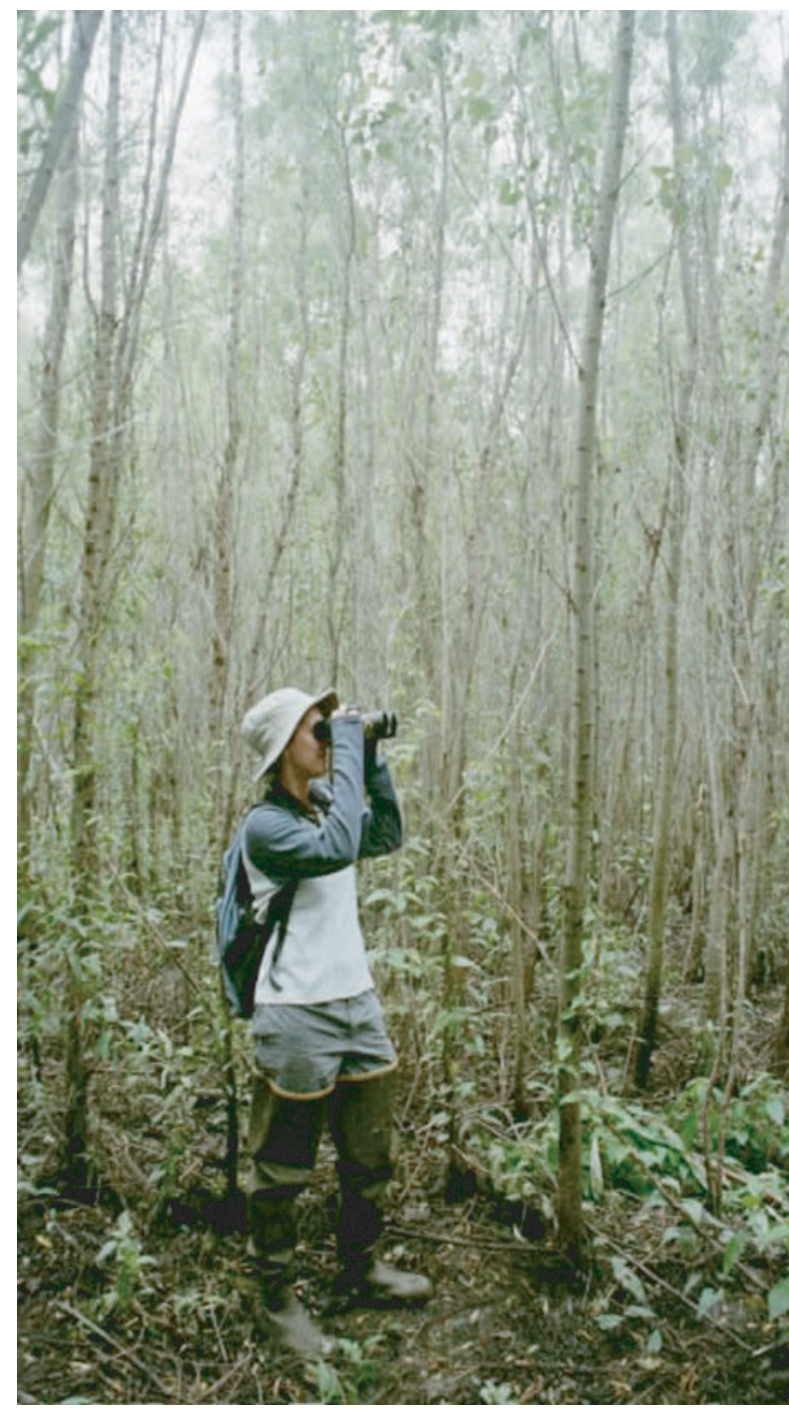

Young forests comprise primarily willow (Salix spp.) and cottonwood (Populus deltoides) trees established on abandoned agricultural land after the 1993 flood on the Mississippi River. 